\title{
Prevalence, genetic, and biochemical evaluation of immune response of police dogs infected with Babesia vogeli
}

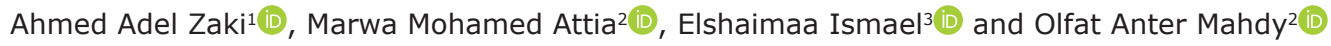 \\ 1. Veterinary Health Care Unit at k9-Departmeant of Police Academy, First settlement at Cairo, Egypt; 2. Department of \\ Parasitology, Faculty of Veterinary Medicine, Cairo University, 12211 Giza, Egypt; 3. Department of Veterinary Hygiene \\ and Management, Faculty of Veterinary Medicine, Cairo University, Giza 12211, Egypt. \\ Corresponding author: Olfat Anter Mahdy, e-mail: dr.olfat.mahdy@cu.edu.eg \\ Co-authors: AAZ: vetdrahmed@hotmail.com, MMA: marwaattia.vetpara@yahoo.com, EI: elshaimaavet@gmail.com
}

Received: 10-11-2020, Accepted: 25-02-2021, Published online: 15-04-2021

doi: www.doi.org/10.14202/vetworld.2021.903-912 How to cite this article: Zaki AA, Attia MM, Ismael E, Mahdy OA (2021) Prevalence, genetic, and biochemical evaluation of immune response of police dogs infected with Babesia vogeli, Veterinary World, 14(4): 903-912.

\begin{abstract}
Background and Aim: Babesia species are tick-borne protozoan parasites of apicomplexan type which infect the erythrocytes of dogs it ranges from subclinical to severe cases, depending on different factors such as immune status, age, and presence of other co-infections with the Babesia species. Hence, this study aimed to identify the protozoan parasites infecting police dogs of different breeds, ages, and both sexes in Egypt. Concerning molecular detection of Babesia vogeli using conventional polymerase chain reaction sequencing and phylogenetic analysis, followed by the assessment of immunological and biochemical status of infected dogs.
\end{abstract}

Materials and Methods: The blood of 242 police K9 dogs was collected. The age, breed, sex, and health status with clinical signs of dogs were recorded. Hematological, biochemical, and oxidative stress analyses of the blood were performed together with gene expression analysis using two genes (gamma interferon [IFN- $\gamma$ ] and tumor necrosis factor-alpha [TNF$\alpha]$ ). The identification of the causative agent was performed using molecular analysis of the 18S ribosomal RNA (rRNA). The 18S rRNA region of canine Babesia spp. was successfully amplified, and sequencing data were deposited in GenBank (accession number: MT565474.1), which resembled those of B. vogeli.

Results: The results of blood samples screening revealed that of the 242 blood samples, 62 were positive for $B$. vogeli infection. The infection rate in male dogs was higher than that in female dogs. The police dogs were classified into the following three groups of dogs: ( $1^{\text {st }}$ group) healthy, $\left(2^{\text {nd }}\right.$ infected with B. vogeli, and mixed infection of B. vogeli and Ehrlichia canis). The oxidative stress biomarkers levels in $B$. vogeli infected dogs were greater than that of healthy dogs. Likewise, IFN- $\gamma$ and TNF- $\alpha$ level in B. vogeli infected dogs were elevated in infected dogs.

Conclusion: Our findings demonstrated that $B$. vogeli had completely adverse effects on the health condition of the police dogs that may lead to death in some dogs.

Keywords: Babesia vogeli, Egypt, Ehrlichia canis, police dogs, tumor necrosis factor-alpha.

\section{Introduction}

Dogs have several roles, for example, being a guard dog and in explosive and narcotic detection. These dogs may have several diseases such as bacterial, viral, and parasitic infections. Tick infection is one of the most common diseases in dogs; there are several protozoan parasites that infect these dogs, including Babesia canis, Hepatozoon canis, and Ehrlichia canis [1]. Babesiosis and ehrlichiosis are the most common, especially in summer. The infected dogs experience thrombocytopenia that characterizing babesiosis and hyperglobulinemia that characterizing ehrlichiosis [2,3]. The clinical signs of babesiosis in dogs include fever, hemolysis of red blood cells

Copyright: Zaki, et al. Open Access. This article is distributed under the terms of the Creative Commons Attribution 4.0 International License (http://creativecommons.org/licenses/by/4.0/), which permits unrestricted use, distribution, and reproduction in any medium, provided you give appropriate credit to the original author(s) and the source, provide a link to the Creative Commons license, and indicate if changes were made. The Creative Commons Public Domain Dedication waiver (http://creativecommons.org/ publicdomain/zero/1.0/) applies to the data made available in this article, unless otherwise stated. with anemia, hyperbilirubinemia, hemoglobinuria, jaundice, and organ failure $[4,5] B$. canis are tickborne protozoan parasites of apicomplexan type that infect the erythrocytes of dogs [6-8]. Babesiosis ranges from subclinical to severe cases, depending on different factors such as immune status, age, and presence of other co-infections with the Babesia spp. $[9,10]$. The diagnosis of babesiosis depends on the microscopic detection of the intraerythrocytic piroplasms in peripheral blood smears $[10,11]$.

The significance of this study as mentioned in a recent study by Badawi and Yousif [12] provides the molecular record and phylogenetic analysis of B. canis in dogs in Iraq, and it will be valuable to confirm clinical signs and study epidemiological risk factors of babesiosis in dogs. However, various species from the genus Babesia (B. canis, Babesia vogeli, and Babesia rossi) cannot be differentiated through microscopic examination of blood films, despite differences in their genetics, pathology, and vector associations [13].

Therefore, this study aimed to identify the protozoan parasites infecting police dogs of different 
breeds, ages, and both sexes in Egypt by interrupting the molecular detection of $B$. vogeli using conventional polymerase chain reaction (PCR) sequencing and phylogenetic analyses, followed by the assessment of immunological and biochemical status of infected dogs.

\section{Materials and Methods}

\section{Ethical approval}

Institutional and National guidelines for the care and use of animals were followed as directed by Faculty of Veterinary Medicine, Cairo University.

\section{Study period and location}

The study was conducted from August 2017 to December 2019. Samples were collected at Veterinary Health Care Unit at K9-Department of Police Academy and processed at Biotechnology Laboratory, Cairo University Research Park.

\section{Sample collection}

A total of 242 blood samples were collected from police dogs at (K9-department) in police Academy located in the first settlement in Cairo, Egypt. The survey was conducted along various seasons, from
August (Summer), October (Autumn), December and February (Winter), as well as April and June (Spring). The ages of the dogs ranged between 2.5 and 12 years. General inspection indicated that 180 police dogs were healthy without visible clinical signs. However, 62 dogs exhibited clinical manifestations such as fever, emaciation, anemia, nostril and anal bleeding, edema, jaundice, and bloody urine. Many ways of control were used to eradicate and prevent further infection and infestation of ticks and protozoal parasites using tick repellents and antiprotozoal drugs. The detailed information, such as sex, breed, age, and health status of these dogs as well as season, is presented in Table1. Across all samples, the percentage of female dogs was $16.12 \%$ (39 of 242), whereas the percentage of male dogs was $83.88 \%$ (203 of 242).

\section{Collection of blood samples}

Blood samples were collected from the cephalic vein of 242 police dogs; each sample was divided into two parts: One with ethylenediaminetetraacetic acid (EDTA) as an anticoagulant for preparing the examination of blood films and DNA extraction and the

Table-1: Prevalence of Babesia in Police dogs from Egypt $(n=242)$.

\begin{tabular}{|c|c|c|c|c|c|}
\hline \multirow[t]{2}{*}{ Variables } & \multirow[t]{2}{*}{$\begin{array}{l}\text { No. of tested dogs } \\
(\%)(n=242)\end{array}$} & \multicolumn{2}{|c|}{$\begin{array}{c}\text { Babesia infected dogs } \\
(n=62 / 242)\end{array}$} & \multicolumn{2}{|c|}{$\begin{array}{l}\text { Mixed infection with } \\
\text { Ehrlichia }(n=28 / 62)\end{array}$} \\
\hline & & No. (\%) & CI 95\% & No. (\%) & CI 95\% \\
\hline \multicolumn{6}{|l|}{ Breeds: } \\
\hline German shepherd & $182(75.21)$ & $51(28.02)$ & $21.5-34.6$ & $24(47.06)$ & $33.4-60.8$ \\
\hline Malinois & $52(21.49)$ & $10(19.23)$ & $8.5-29.9$ & $4(40.00)$ & $9.6-70.4$ \\
\hline Dutch Shepherd & $7(2.89)$ & 0.0 & 0.0 & 0.0 & 0.0 \\
\hline Belgian shepherd & $1(0.41)$ & $1(100)$ & 100 & 0.0 & 0.0 \\
\hline $\mathrm{p}$-value & & 0.071 & & 0.858 & \\
\hline \multicolumn{6}{|l|}{ Gender: } \\
\hline Female & $39(16.12)$ & $8(20.51)$ & $7.8-33.2$ & $4(50.00)$ & $15.4-84.7$ \\
\hline Male & $203(83.88)$ & $54(26.60)$ & $20.5-32.7$ & $24(44.44)$ & $31.2-57.7$ \\
\hline p-value & & 0.425 & & 1.000 & \\
\hline \multicolumn{6}{|c|}{ Intensity of tick infection: } \\
\hline No & $108(44.63)$ & 0.0 & 0.0 & 0.0 & 0.0 \\
\hline Mild & $37(15.29)$ & 0.0 & 0.0 & 0.0 & 0.0 \\
\hline Moderate & $53(21.90)$ & $24(45.28)^{b}$ & $31.9-58.7$ & $10(41.67)$ & 21.9-61.4 \\
\hline Severe & $44(18.18)$ & $38(86.36)^{a}$ & $76.2-96.5$ & $18(47.37)$ & $31.5-63.2$ \\
\hline p-value & & $<0.0001$ & & 0.660 & \\
\hline \multicolumn{6}{|l|}{ Age (years): } \\
\hline$\leq 3$ & $62(25.62)$ & $9(14.52)$ & $0.0-32.2$ & $1(11.11)^{\mathrm{b}}$ & $0.0-31.6$ \\
\hline $4-6$ & $86(35.54)$ & $26(30.23)$ & 20.5-39.9 & $12(46.15)^{a b}$ & $26.9-65.3$ \\
\hline $7-9$ & $83(34.30)$ & $25(30.12)$ & $20.3-39.9$ & $15(60.00)^{a}$ & $40.8-79.2$ \\
\hline$\geq 10$ & $11(4.55)$ & $2(18.18)$ & $0.0-40.9$ & 0.0 & 0.0 \\
\hline p-value & & 0.103 & & 0.035 & \\
\hline \multicolumn{6}{|l|}{ Health status: } \\
\hline Normal & $180(66.12)$ & $0.0^{\mathrm{b}}$ & 0.0 & 0.0 & 0.0 \\
\hline Clinical signs & $62(33.88)$ & $62(75.61)^{\mathrm{a}}$ & $66.3-84.9$ & $27(43.55)$ & $31.2-55.9$ \\
\hline P-value & & $<0.0001$ & & & \\
\hline \multicolumn{6}{|l|}{ Status: } \\
\hline Live & $182(75.21)$ & $9(3.72)^{\mathrm{b}}$ & $1.8-8.1$ & $1(11.11)$ & $0.0-31.6$ \\
\hline Died & $60(24.79)$ & $53(88.33)^{a}$ & $80.2-96.5$ & $26(49.06)$ & $35.6-62.5$ \\
\hline p-value & & $<0.0001$ & & 0.065 & \\
\hline \multicolumn{6}{|l|}{ Season: } \\
\hline Autumn & 37 (15.29) & $21(56.76)^{a}$ & $40.8-72.7$ & $11(52.38)$ & $31.0-73.7$ \\
\hline Winter & 72 (29.75) & $26(36.11)^{b}$ & $25.0-47.2$ & $14(53.85)$ & $34.7-73.0$ \\
\hline Spring & $41(16.94)$ & $6(14.63)^{c}$ & $3.8-25.5$ & $1(16.67)$ & $0.0-61.7$ \\
\hline Summer & $92(38.02)$ & $9(9.78)^{c}$ & 3.7-15.9 & $1(11.11)$ & $0.0-31.6$ \\
\hline p-value & & $<0.0001$ & & 0.060 & \\
\hline
\end{tabular}

$a, b, c$ Different superscripts within the same column indicate significance at $\mathrm{P}<0.05 ;$ CI $95 \%=$ Confidence interval $95 \%$ 
second one without an anticoagulant for serum separation for biochemical analysis.

\section{Parasitological examination}

The blood smears were placed on a clean slide, air dried, fixed in absolute methyl alcohol for $10 \mathrm{~min}$, and Giemsa stained as per the manufacturer's instruction. The smears were washed with tap water to remove extra stains and then air-dried. The stained blood smears were examined by light microscopy $(\times 40$ and $\times 100)$ (OLYMPUS CX41, Japan) for the detection of blood parasites.

Hematological analysis of blood infected with $B$. canis

A total of 180 whole blood samples with EDTA were subjected into hematological analysis to determine different blood parameters that could be changed during babesiosis infection in dogs. In addition, sera were subjected to biochemical analysis to determine aspartate aminotransferase (AST), alanine aminotransferase (ALT), and C-reactive protein (CRP) using specific test kits (Spectrum Diagnostics, Egypt) $[14,15]$

PCR analysis of the blood for identification of the B. canis subspecies

Molecular analysis of frozen blood from infested dogs with babesiosis was subjected to DNA extraction. The DNA was extracted from $200 \mu \mathrm{L}$ of blood using the DNA blood kit (QIAGEN, Hilden, Germany) in the automatic extraction system QIAcube (QIAGEN). In each round of extraction, one sample of DNase/ RNase-Free distilled water was included as a blind control for DNA extraction. To detect members of the genera Babesia, a fragment ( $\sim 560 \mathrm{bp})$ of the $18 \mathrm{~S}$ ribosomal RNA (rRNA) gene was amplified and sequenced using the forward primer PIRO-A (5'AATACCCAATCCTGACACAGGG-3') and PIRO-B (5'-TTAAATACGAAT GCCCCCAAC-3') that amplify complete $18 \mathrm{~S}$ rRNA gene under conditions described by Olmeda et al. [16]. The PCR cycling was: Initial denaturation for $2 \mathrm{~min}$ at $95^{\circ} \mathrm{C}$ for denaturation, annealing $30 \mathrm{~s}$ at $55^{\circ} \mathrm{C}$, and $30 \mathrm{~s}$ at $72^{\circ} \mathrm{C}$ for extension and a finally $5 \mathrm{~min}$ at $72^{\circ} \mathrm{C}$ for extension. The resulting sequences were assembled using the SeqMan Pro software, edited with Edit Seq tools in Lasergene (DNASTAR, Inc., Madison, WI, USA) and compared with available sequences using Basic Local Alignment Search Tool (BLAST) in GenBank.

\section{Measurement of oxidative stress markers}

Different parameters of oxidative stress were evaluated in sera. The levels of malondialdehyde (MDA), superoxide dismutase (SOD), and catalase were evaluated using the positive and negative sera with the specific kit analysis $[17,18]$.

Evaluation of tumor necrosis factor-alpha (TNF- $\alpha$ ) and gamma interferon (IFN- $\gamma$ ) activity

Blood samples from the infected dogs had $B$. vogeli with blood films, and blood samples from five young reared uninfected puppies were collected in a similar manner and used as negative controls. All blood samples were aseptically preserved in $-20^{\circ} \mathrm{C}$.

\section{$R N A$ isolation}

RNA isolation from $100 \mathrm{mg}$ of blood was performed by a total RNA kit (Ambion, Applied Biosystems, USA) per the manufacturer's instructions. The Thermo Scientific Nano-Drop was used to measure the RNA purity and quantity. Notably, 500 ng of RNA was made with DNase I amplification grade (Invitrogen, Germany) per the manufacturer's instructions. The reverse transcription of treated RNA was performed by High-Capacity cDNA Archive Kit (Applied Biosystems) [19].

\section{Quantitative real-time PCR protocol}

PCR primer set specific for TNF- $\alpha$ and IFN- $\gamma$ specific for dogs was designed and based on sequences deposited in the GenBank. $\beta$-actin was used as a reference gene and for sample normalization. The gene expression included in this study was tested on a separate pool of cDNA, generated from five uninfected dogs previously examined for the presence of any parasites [20].

\section{Statistical analysis}

The PASW Statistics version 18.0 software (SPSS Inc., Chicago, IL, USA) was used for data analysis. The Chi-square $\left(\chi^{2}\right)$ test or Fisher's exact test (FET) was used to determine the differences between Babesia infection rates under various parameters. Hematological, biochemical, oxidative stress, and gene expression parameters of healthy and diseased dogs were compared by one-way analysis of variance and independent sample t-test and expressed as mean \pm standard error. $p<0.05[21]$ was considered statistically significant.

\section{Results}

Morphological identification of the protozoan parasite

The infected dogs experienced tick infection from the genus Rhipicephalus sanguineus (Figure-1) which was identified by a light microscope. The examined stained blood smears revealed the presence of $B$. canis with a large form (3-5.5 $\mu \mathrm{m}$ in length). Each piroplasma was pyriform in shape, pointed at one end and round at the other end (Figure-1).

\section{Molecular identification of $B$. canis infected police dogs}

The 18S rRNA region of canine Babesia spp. was successfully amplified using the universal primers mentioned earlier in this study. Purified PCR products from this blood protozoan parasite was directly sequenced and yielded $554 \mathrm{bp}$ of three specimens. These sequences were deposited in GenBank (accession number: MT565474.1). The comparison of these DNA sequences fragments with other nucleotide sequences and the divergence of $B$. canis canis and $B$. vogeli in GenBank indicated that this species was identified and confirmed as $B$. vogeli. 


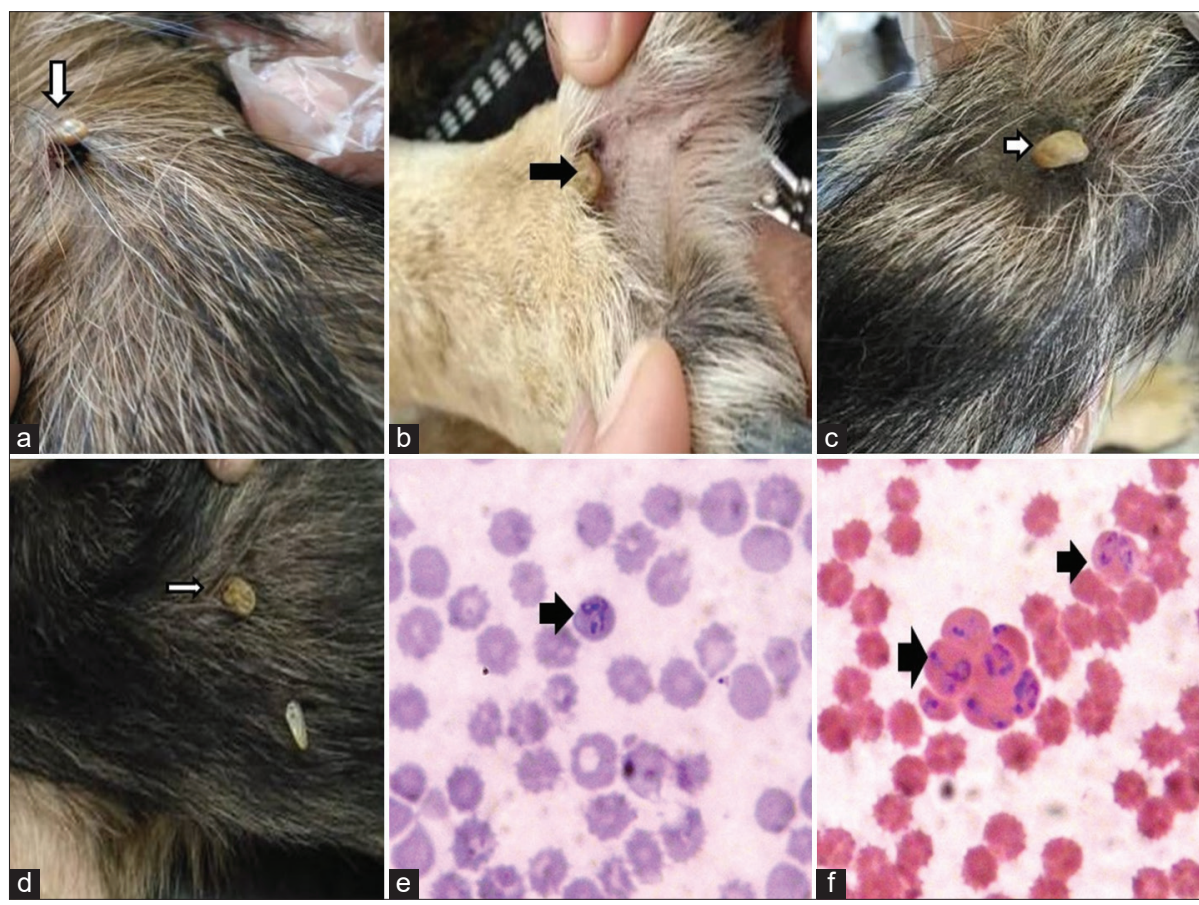

Figure-1: Ticks (Rhipicephalus sanguineus which identified by light microscope infection in Police dogs (A-D), E: F: stained blood smears revealed presence of Babesia vogeli with large form (3-5.5 $\mu \mathrm{m}$ in length). Each piroplasma was pyriform in shape, pointed at one end, and round at other end using $100 \times$.

The BLAST analysis of B. vogeli (MT565474.1) of this study revealed $100.0 \%$ nucleotide identity with B. vogeli (AY371197.1 in Egypt and HQ662635.1 in Romania), $99.61 \%$ nucleotide similarity with B. vogeli (KT333456.1 in Brazil and KM199636.1 in Thailand), $96.41 \%$ nucleotide similarity with B. vogeli (MK674799.1 in France), 99.21\% similarity (MT740272.1) in Kenya and HQ148663 in Taiwan, and $98.62 \%$ and $98.52 \%$ nucleotide similarity with B. vogeli (DQ439545.1 and AY150061.1 in Spain). In contrast, the present nucleotide similarity with $B$. canis canis was 96.08\% nucleotide similarity (KX839230.1 in Italy, EU622793.1 in Poland, KF499115.1 in Turkey, HQ662634.1 in Romania, and FJ209025.1 in Croatia).

The derived phylogenetic tree based on the neighbor-joining model using the $18 \mathrm{~S}$ rRNA region of $B$. vogeli revealed Two strong nodal supports of $B$. canis major clades. The first clade included $B$. canis grouped with $B$. vogeli and the second clade included $B$. canis canis to form two subclades. The first subclade of $B$. vogeli grouped Egypt and Romania together and separated from other groups of B. canis canis (Figure-2).

\section{Prevalence study of $B$. vogeli in police dogs}

The results of blood samples screening revealed that of the 242 blood samples, 62 were positive for B. vogeli infection $(25.62 \%$ [62 of 242$]$; $95 \%$ confidence interval [CI], 20.12-31.12) (Table-1). No significant association was observed between the breed of dogs and $B$. vogeli infection rates $(\mathrm{p}=0.071$; FET). The infection rate in male dogs $(26.60 \%$ [54 of 203]; $95 \%$ CI, 20.52-32.68) was higher than in female dogs (20.51\% [8 of 39]; 95\% CI, 7.84-33.19); however, the difference was not significant $\left(\chi^{2}[1, \mathrm{~N}=242]=\right.$

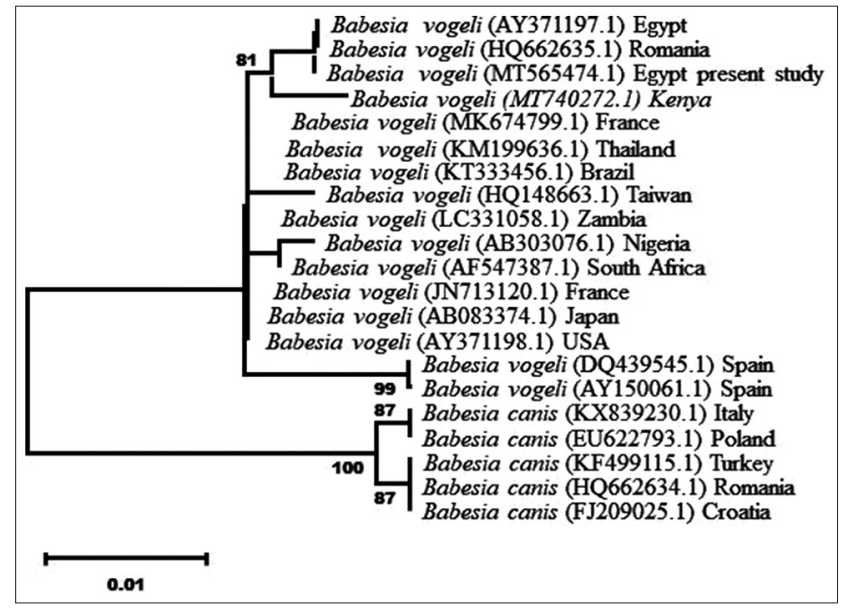

Figure-2: Phylogenetic tree of the $18 \mathrm{~S}$ rDNA gene sequences created using the neighbor-joining method and bootstrap analysis of 500 replicates. Sequences with accession numbers have been taken from GenBank for comparison. The sample sequenced in the present study represents another identical sequence of the first genetic variant detected in this study (GA combination).

$0.636 ; \mathrm{p}=0.425)$. Meanwhile, no significant association was observed among the various ages of $\operatorname{dogs}\left(\chi^{2}\right.$ $[3, \mathrm{~N}=242]=0.617 ; \mathrm{p}=0.103)$. Notably, the infection rate in dogs that were severely infected with ticks was higher than those with lower rates of infection $\left(\chi^{2}[3\right.$, $\mathrm{N}=242]=145.90 ; \mathrm{p}<0.0001)$, and dogs showing clinical signs presented a significantly higher infection rate than the apparently normal dogs $\left(\chi^{2}[1, \mathrm{~N}=242]\right.$ $=162.65 ; \mathrm{p}<0.0001)$. Similarly, the detection rate of Babesia in dead dogs was significantly higher than in living $\operatorname{dogs}\left(\chi^{2}[1, \mathrm{~N}=242]=164.66 ; \mathrm{p}<0.0001\right)$. 
Furthermore, the infection rates in autumn and winter were significantly higher than that in spring and sum$\operatorname{mer}\left(\chi^{2}[3, \mathrm{~N}=242]=37.69 ; \mathrm{p}<0.0001\right)$.

Detection of mixed infection with $B$. vogeli and E. canis

The results of blood samples screening revealed that of the 62 positive Babesia blood samples, 28 were positive for E. canis infection (45.16\% [28 of 62]; $95 \%$ CI, 32.77-57.55) (Table-1). No significant association was observed between the breed of dogs $(\mathrm{p}=0.858$; FET), sex $(\mathrm{p}=0.530$; FET $)$, alive or dead status $(\mathrm{p}=0.065 ; \mathrm{FET})$, intensity of tick infection $\left(\chi^{2}[1\right.$, $\mathrm{N}=62]=0.193 ; \mathrm{p}=0.660)$, season of the year $(\mathrm{p}=0.060$; FET), and rates of mixed Babesia and E. canis infection. Notably, the rates of mixed Babesia and E. canis infection in older dogs were significantly higher than in younger ones ( $p=0.035$; FET).

\section{Hematological and biochemical analysis}

Hematological and biochemical results of sampled police dogs were classified into three groups, that is, healthy dogs, dogs infected with $B$. vogeli, and dogs that acquired mixed infection of Babesia and E. canis (Table-2). The hematology results of the sampled police dogs are presented in Table-2. Infected dogs exhibited lower hemoglobin concentration, packed cell volume (PCV), and total erythrocyte count than healthy dogs. Most of the dogs with low hematological values also clinically manifested anemia. Notably, low platelet count and leukopenia were observed in dogs with mixed Babesia and E. canis infection.

The biochemical results of the serum samples obtained from police dogs are presented in Table-2. High AST and ALT levels were observed in both dogs infected with Babesia and dogs that acquired mixed $B$. vogeli and $E$. canis infection, which indicated liver damage. Symptoms of liver damage clinically manifested as edema and jaundice. Increased levels of creatinine and blood urea nitrogen were observed in dogs infected with Babesia and dogs that acquired mixed $B$. vogeli and E. canis infection, which indicated renal failure. Symptoms of renal failure clinically manifested as emaciation and bloody urine.

\section{Oxidative stress}

On average, MDA levels in B. vogeli infected dogs $(5.72 \pm 1.41)$ were greater than that of healthy dogs $(1.50 \pm 0.01)$. This mean difference $(4.22 \mathrm{nmol} / \mathrm{mL}$ $[95 \% \mathrm{CI}, \pm 4.49])$ was not significant $(t[d f=6]=2.25$; $\mathrm{p}=0.065$ ). Similarly, CAT levels in Babesia infected dogs $(5326.80 \pm 1139.70)$ were greater than that in healthy dogs $(2554.00 \pm 0.58)$. This mean difference $(2772.80 \mathrm{nmol} / \mathrm{mL}[95 \% \mathrm{CI}, \pm 3164.33])$ was not significant $(t[4]=2.43 ; \mathrm{p}=0.072])$. However, SOD levels in Babesia infected dogs (7101.40 \pm 1439.28$)$ were greater than that in healthy dogs $(1997.67 \pm 1.33)$. This mean difference $(5103.73 \mathrm{nmol} / \mathrm{mL}[95 \% \mathrm{CI}, \pm 4695.71])$ was significant $(t[6]=2.66 ; \mathrm{p}=0.038])$. Moreover, CRP levels in Babesia infected dogs $(95.85 \pm 18.88)$ were greater than that in healthy dogs $(3.50 \pm 0.38)$. This mean difference $(92.35[95 \% \mathrm{CI}, \pm 42.71])$ was significant $(t[6]=$ $4.89 ; \mathrm{p}=0.001]$ ) (Table-3, Figure-3).

\section{Gene expression analysis}

Likewise, IFN- $\gamma$ levels in Babesia infected dogs $(8.20 \pm 1.16)$ were greater than that in healthy dogs (3.33 \pm 0.17$)$. This difference $(4.87[95 \%$ CI, -8.66 to -1.08$]$ ) was significant ( $\mathrm{t}[6]=-3.14 ; \mathrm{p}=0.020]$ ). In addition, TNF- $\alpha$ levels in Babesia infected dogs $(10.60 \pm 1.96)$ were greater than that in healthy dogs (2.97 \pm 0.03$)$. This difference $(7.63 \mathrm{U} / \mathrm{mL}[95 \% \mathrm{CI}$, -14.04 to -1.22$]$ ) was significant (t [6] $=-2.91$; $\mathrm{p}=0.027])($ Table-3, Figure-4).

Table-2: Hematological and biochemical parameters in healthy and infected dogs $(n=180)$

\begin{tabular}{|c|c|c|c|c|c|}
\hline \multirow{2}{*}{$\begin{array}{l}\text { Parameters (normal/ } \\
\text { reference range) }\end{array}$} & \multicolumn{3}{|c|}{ Mean \pm SE } & \multirow[t]{2}{*}{$F(2,177)$} & \multirow[t]{2}{*}{ p - value } \\
\hline & $\begin{array}{l}\text { Healthy dogs } \\
(n=127)\end{array}$ & $\begin{array}{l}\text { Babesia infected } \\
\text { dogs }(n=27)\end{array}$ & $\begin{array}{c}\text { Mixed Babesia and } \\
\text { Ehrlichia infection }(n=26)\end{array}$ & & \\
\hline \multicolumn{6}{|l|}{ Hematology: } \\
\hline $\begin{array}{l}\text { Total erythrocyte } \\
\text { count }\left(5.5-8.5 \times 10^{6} \mu \mathrm{l}\right)\end{array}$ & $6.92 \pm 0.08^{a}$ & $4.44 \pm 0.15^{b}$ & $4.43 \pm 0.23^{b}$ & 142.19 & $<0.0001 *$ \\
\hline $\begin{array}{l}\text { Hemoglobin } \\
\text { concentration }(12-18 \mathrm{~g} \%)\end{array}$ & $14.33 \pm 0.13^{a}$ & $8.97 \pm 0.49^{b}$ & $9.56 \pm 0.29^{b}$ & 177.06 & $<0.0001$ \\
\hline Platelet count $\left(200-900 \times 10^{2} \mu \mathrm{l}\right)$ & $264.21 \pm 6.40^{\mathrm{a}}$ & $240.44 \pm 14.75^{a}$ & $58.12 \pm 14.24^{b}$ & 86.56 & $<0.0001$ \\
\hline $\begin{array}{l}\text { Packed cell } \\
\text { volume (Hematocrit) }(37-55 \%)\end{array}$ & $40.44 \pm 0.52^{\mathrm{a}}$ & $35.04 \pm 0.27^{b}$ & $34.44 \pm 0.47^{\mathrm{b}}$ & 24.26 & $<0.0001$ \\
\hline $\begin{array}{l}\text { Total leukocyte } \\
\text { count }\left(6-17 \times 10^{6} \mu \mathrm{l}\right)\end{array}$ & $10.12 \pm 0.26^{a}$ & $10.27 \pm 0.52^{\mathrm{a}}$ & $4.36 \pm 0.34^{b}$ & 49.88 & $<0.0001$ \\
\hline \multicolumn{6}{|l|}{ Biochemical: } \\
\hline AST (8-48 IU/L) & $40.46 \pm 1.35^{b}$ & $94.15 \pm 6.15^{\mathrm{a}}$ & $84.38 \pm 5.11^{\mathrm{a}}$ & 110.28 & $<0.0001$ \\
\hline ALT (8-58 IU/L) & $51.39 \pm 1.62^{b}$ & $120.74 \pm 5.46^{\mathrm{a}}$ & $117.42 \pm 4.86^{\mathrm{a}}$ & 193.93 & $<0.0001$ \\
\hline Creatinine $(0.5-1.6 \mathrm{mg} \%)$ & $0.91 \pm 0.17^{c}$ & $1.89 \pm 0.08^{\mathrm{b}}$ & $2.20 \pm 0.08^{a}$ & 323.65 & $<0.0001$ \\
\hline $\begin{array}{l}\text { Blood urea nitrogen } \\
(8.8-26 \mathrm{mg} \%)\end{array}$ & $26.13 \pm 0.37^{c}$ & $55.44 \pm 3.36^{b}$ & $66.46 \pm 3.07^{a}$ & 253.19 & $<0.0001$ \\
\hline
\end{tabular}

$a, b, c$ Different superscripts within the same row indicate significant difference at $\mathrm{P}<0.05$ and confidence level $95 \%$; $\mathrm{SE}=$ Standard error, $\mathrm{AST}=$ Aspartate aminotransferase, $\mathrm{ALT}=$ Alanine aminotransferase. $F(2,177)$ : $F$-value (degree of freedoms between groups, degree of freedoms within groups). *When the statistical test gives a $P$ result $=0.000$, we express it as $<0.0001$ 

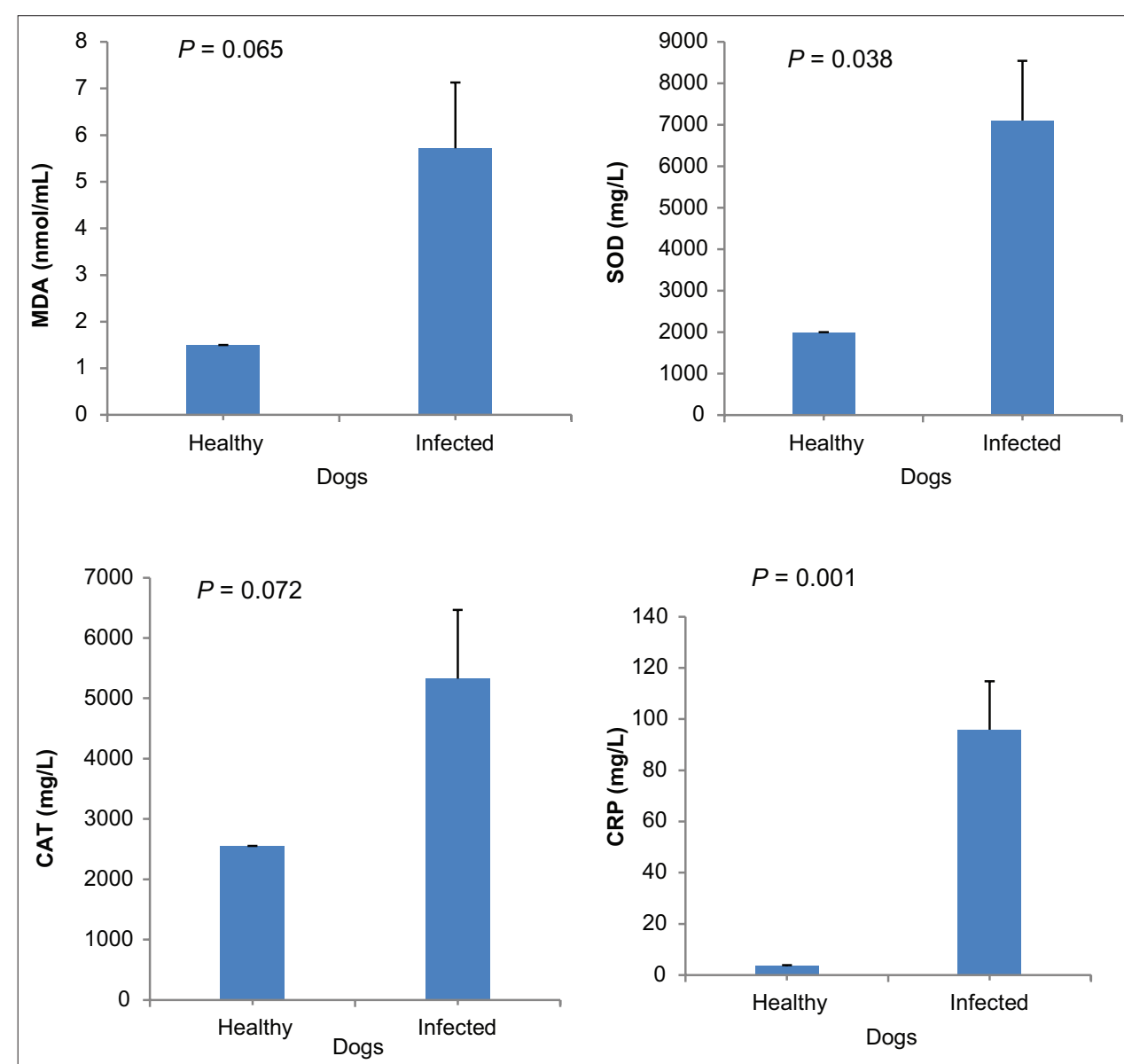

Figure-3: $\mathrm{MDA}=$ Malondialdehyde; $\mathrm{SOD}=$ Superoxide dismutase; $\mathrm{CAT}=$ Catalase and CRP (C-reactive protein). Significance was indicated at $p<0.05$.

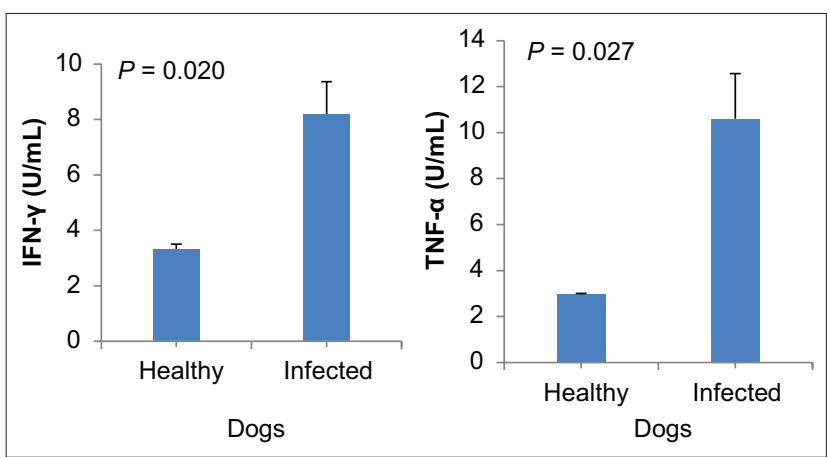

Figure-4: IFN- $\gamma=$ Gamma-interferon; TNF- $a=$ Tumor necrosis factor alpha. Significance was indicated at $p<0.05$.

\section{Discussion}

In this study, we investigated the prevalence of 2 tick-borne pathogens in police working dogs in Egypt. Our results indicated the prevalence of $B$. vogeli $(25.62 \%)$ and E. canis $(11.57 \%)$. The previous studies reported that the prevalence of Babesia spp. in dogs ranged from $1.2 \%$ to $11.3 \%$ in China [22,23], $10.9 \%$ to $19.09 \%$ in India [24], 14.0\% in Southern Italy [25], and $61.1 \%$ in Nigeria [26]. Results showed that breed, sex, and age did not significantly influence the incidence of B. vogeli, which agreed with. Adebayo et al. [26]. Canine babesiosis did not take enough consideration in research work in Egypt compared with other animal species [27]. Other studies investigated that the prevalence of E. canis in dogs was $10.3 \%$ in Korea [28], 1.3\% in Southern China [29], 44.6\% in North Trinidad [30], 29.26\% in Mexico [31], and $40.6 \%$ in Colombia [32]. Although our study contradicts with reports on age difference regarding positivity to $E$. canis, there was a significant increase in E. canis infection rate in older dogs ( 7 years of age and older), which suggests that acquiring infection increases with age [30]. The diverse patterns for canine tick-borne pathogens among different countries may be attributed to the differences in the tick distribution [28].

The current study noted that the rate of Babesia infection increased by age ( $>3$ years) and declined after the age of 9 years; however, the difference was not significant. This result is consistent with Salem and Farag [27] who reported that the highest infections were found in the age group of 3-5 years and explained that Babesia infection was known to increase by age, reaching its peak between the age of 3 and 5 years and then peter out [33]. Similarly, older years of age emerged as a risk factor for B. canis/B. vogeli sero-reactivity as suggested in the study by Veneziano et al. [25]. They stated that this finding is probably caused by the cumulative exposure to the relevant tick vectors rather than an increased susceptibility to the Babesia infection. However, 
Table-3: Oxidative stress and gene expression parameters in healthy and infected dogs.

\begin{tabular}{|c|c|c|c|c|}
\hline Oxidative stress and gene expression parameters & Healthy dogs & Babesia infected dogs & $t(d f)$ & p-value \\
\hline MDA (nmol/mL) & $1.50 \pm 0.00$ & $5.72 \pm 1.41$ & $-2.25(6)$ & 0.065 \\
\hline $\mathrm{SOD}(\mathrm{mg} / \mathrm{L})$ & $1997.67 \pm 1.33^{b}$ & $7101.40 \pm 1439.28^{a}$ & $-2.66(6)$ & 0.038 \\
\hline CAT $(\mathrm{mg} / \mathrm{L})$ & $2554.00 \pm 0.58$ & $5326.80 \pm 1139.70$ & $-2.43(4)$ & 0.072 \\
\hline CRP (mg/L) & $3.50 \pm 0.38^{b}$ & $95.85 \pm 18.88^{\mathrm{a}}$ & $-4.89(9)$ & 0.001 \\
\hline IFN-Y $(U / m L)$ & $3.33 \pm 0.17^{b}$ & $8.20 \pm 1.16^{a}$ & $-3.14(6)$ & 0.02 \\
\hline TNF-a (U/mL) & $2.97 \pm 0.03^{b}$ & $10.60 \pm 1.96^{a}$ & $-2.91(6)$ & 0.027 \\
\hline
\end{tabular}

a,bDifferent superscripts within the same row indicate significant difference at $p<0.05$. MDA=Malondialdehyde, $\mathrm{SOD}=$ Superoxide dismutase, $\mathrm{CAT}=$ Catalase, $\mathrm{CRP}=\mathrm{C}$-reactive protein, IFN $-\mathrm{\gamma}=$ Gamma interferon, $\mathrm{TNF}-\mathrm{a}=$ Tumor necrosis factor-alpha

other previous studies indicated that although canine babesiosis can occur in animals of all ages, young animals are more susceptible to Babesia infection and exhibited more severe clinical manifestations [23].

Furthermore, the current study remarked non-significant higher rates of infection in male dogs than females, which agrees with Mellanby et al. and Veneziano et al. $[25,34]$ who stated that male dogs exhibited an increased risk of developing canine babesiosis, because they have a higher environmental exposure due to increased roaming behavior. Salem and Farag [27] stated that male dogs exhibited a higher infection rate than female ones; the aggressiveness and hormonal status of male dogs may be a contributory factor here. However, Martinod et al. [35] found no difference in sex susceptibility between males and females.

The study indicated that the rate of Babesia infection was not dependent on the breed of the surveyed dogs. However, earlier studies indicated a significantly higher seroprevalence in long-hair dogs, in which hard ticks can easily attach and avoid detection [25]. In addition, a breed predisposition has been suggested in Hungary, citing the vulnerability of the German shepherd breed to developing babesiosis caused by $B$. canis [33]. Salem and Farag [27] reported that German shepherd dogs seemed to be the breed with the highest infection rate, which was attributed to the prevalence of this breed in Egypt, which agreed with our findings.

Results reported that the rate of $B$. canis infection was significantly dependent on the intensity of tick infection in surveyed dogs. This finding comes in agreement with Farag [36] who reported that the tick population plays a crucial role in the incidence of the infection. Furthermore, the rate of Babesia infection was significantly dependent on the season of the year. The prevalence of Babesia infections was significantly higher in cold months (autumn and winter), which agrees with Farag [36] who stated that climatic condition represents a notable factor in the incidence of the infection. In addition, Veneziano et al. [25] stated that the tick vector favors cool and wet weather.

Babesia infections were significantly associated with the manifestation of clinical signs. The main clinical signs observed were fever, anemia, jaundice, edema, and bleeding. Schetters et al. [37] described the classical presentation of Babesia infections as febrile illness with apparent anemia. Most of the dead dog cases $(88.33 \%)$ were positive for Babesia; $49.06 \%$ of them acquired co-infection with $E$. canis. Adebayo et al. [26] reported that babesiosis accounts for approximately $40 \%$ mortality in the canine cases presented in hospitals in Africa.

In the current study, we reported co-infection with E. canis in 28 of 62 dogs (45.16\%) infected with Babesia. This study reported a significantly higher rate of $B$. vogeli and $E$. canis co-infection in old dogs than young ones. Co-infection with other pathogens, such as E. canis, is common in endemic areas, depending on the geographic location and the distribution of the arthropod vectors. In addition, co-infection is of major clinical relevance, because it complicates diagnoses, intensifies clinical symptoms, diminishes the effectiveness of the medication, and could worsen the prognosis $[38,39]$.

Anemia was the most hematologic alterations observed in $B$. vogeli infected dogs. The mechanisms of inducing anemia have been poorly investigated. Salem and Farag [27] attributed the cause of anemia to the destruction of circulating red blood cells by autoantibodies. Leisewitz et al. [13] stated that the high incidence of hemoglobinuria is testimony to the very important role hemolysis plays in anemia. Thrombocytopenia, anemia, and leukopenia were the most hematologic alterations observed in the dogs that acquired co-infection with E. canis. Thrombocytopenia is the most consistent hematological finding detected in dogs infested with $E$. canis as reported by Frank and Breitschwerdt [40]. These findings agreed with the study by Asgarali et al. [30] who reported that $80.4 \%$ of $E$. canis seropositive dogs had low platelet counts. Moreover, Niwetpathomwat et al. [41] reported severe anemia in 18\%, leukopenia in $19 \%$, and thrombocytopenia in $93 \%$ of the dogs studied. Thrombocytopenia was attributed to multiple causes, such as increased platelet consumption, destruction and sequestration of platelets in the spleen, and co-infection with Babesia $[42,43]$.

The significantly elevated levels of ALT and AST observed in B. vogeli and E. canis infected dogs were frequently reported in the previous studies and indicate the possibility of liver injury after primary infection $[44,45]$. However, Zygner et al. [44] noted that elevated AST levels can also be associated with kidney injury. All blood biochemical indicators of kidney function were significantly higher in $B$. canis infected 
dogs than healthy controls. Zygner et al. [46] in his study on dogs naturally infected with Babesia stated that creatinine was significantly correlated with urea concentration. However, they stated that high creatinine level is considered a poor prognostic indicator.

In our study of the canine babesiosis, there is a correlative association between TNF- $\alpha$ concentration, clinical severity, and parasitemia Zygner et al. [47]. TNF- $\alpha$ and IFN- $\gamma$ play a significant role in the production of several harmful substances such as nitric oxide and free oxygen radicals, which could initiate the interaction between parasitized erythrocytes and the blood vessel wall [48]. Different metabolites of the nitric substance were considered as one of the mediators of multiple organ dysfunction syndromes that are present in canine babesiosis.

This study found a great difference in CRP between healthy and babesiosis-infested canine blood, whereas a study on B. rossi infections showed no differences in CRP levels between survivors and non-survivors [15]. However, an analysis showed that CRP was significantly associated with glucose levels. In dogs with Babesia gibsoni, CRP has a positive correlation with PCV recovery; hence, it could be used as a biomarker of disease condition and clearance [14]. This confirms the idea that the inflammatory mechanisms in canine babesiosis are important to be identified because tissue hypoxia and metabolic dysfunction play a great process in the disease process and condition.

Babesiosis infection was based on a diagnosis made by the morphology of stages of Babesia species within blood cells, but the similarity between species and subspecies was a restricting agent [49]. The PCR method represents a powerful tool for determining not only the genotype but also in which cases symptoms appear nonspecific and/or the blood smears do not present a particular thing the diagnosis. There are recent advances in molecular methodology (methods based on PCR and subsequent DNA sequencing). Genetic characterization was possible to detect and identify piroplasms with greater sensitivity and specificity than conventional ones [50]. Consequently, the knowledge on the prevalence of Babesia species and subspecies infecting police dogs has increased significantly.

Characterization by molecular methods confirmed the presence of three distinct genotypes of $B$. vogeli. Among these, B. vogeli was recognized as the most common agent of canine babesiosis in temperate regions of Europe [51]. In this study, the detected B. vogeli agreed with the results recorded by Elsafey [52], Farag [36], and Abdel-Rhman et al. [53] who reported that B. vogeli was found to naturally infect dogs in Egypt.

Compared with the 18S rRNA sequence obtained through the present BLAST analysis of $B$. vogeli (GenBank accession number: MT565474.1) with other Babesia species, these sequences were completely identical to a $B$. vogeli sequence from Egypt and Romania (AY371197.1 [54] and HQ662635.1 [55], respectively).
The present results indicate a very close genetic relation with $99.61 \%$ nucleotide similarity and the affiliation of the canine Babesia from Brazil (KT333456.1) [56] to B. vogeli. When the present sequences were compared with the sequence of the canine Babesia from B. vogeli, 96.41\% nucleotide similarity was found in France (MK674799.1) [57], whereas 99.21\% similarity was found in Kenya (MT740272.1) [58] and in Taiwan (HQ148663.1) [59]. In contrast, the present nucleotide similarity of $B$. vogeli was compared with $B$. canis canis; $96.08 \%$ nucleotide similarity was found in Italy (KX839230.1)[60],inPoland(EU622793.1)[61],inTurkey (KF499115.1) [62], in Romania (HQ662634.1) [55], and in Croatia (FJ209025.1).

\section{Conclusion}

The causative agent of tick-borne illness in police $\operatorname{dogs}$ was $B$. vogeli. Therefore, from this study, the dogs must be treated against the babesiosis and tick infection together with spraying of the area where the dogs live (ground, dog houses, and walls). Breed disposition, sex, and age did not significantly influence the incidence of $B$. vogeli. The potential contribution of tick exposure, sex, or breed predisposition requires further epidemiological studies.

\section{Authors' Contributions}

AAZ: Collection of the samples. OAM and MMA identified the parasites and did the serological analysis EI: Did the statistical analysis. All authors sharing in writing this manuscript and revised it. All authors have read and approved the final manuscript.

\section{Acknowledgments}

The authors acknowledge the Police Academy for their support in sampling. The authors did not receive any funds for this study.

\section{Competing Interests}

The authors declare that they have no competing interests.

\section{Publisher's Note}

Veterinary World remains neutral with regard to jurisdictional claims in published institutional affiliation.

\section{References}

1. Filipović-Kovačević, M., Beletić, A., Božović-Ilić, A., Milanović, Z., Tyrrell, P., Buch, J., Breitschwerdt, E.B., Birkenheuer, A.J. and Chandrashekaret, R. (2018) Molecular and serological prevalence of Anaplasma phagocytophilum, A. platys, Ehrlichia canis, E. chaffeenses, E. ewingii, Borrelia burgdorferi, Babesia canis, B. gibsoni and $B$. vogeli among clinically healthy outdoor dogs in Serbia. Vet. Parasitol. Reg. Stud. Reports, 14(4): 117-122.

2. Matthewman, L.A., Kelly, P.J., Bobade, P.A., Tagwira, M., Mason, P.R., Majok, A., Brouqui, P. and Raoult, D. (1993) Infections with Babesia canis and Ehrlichia canis in dogs in Zimbabwe. Vet. Rec., 133(14): 344-346.

3. Assarasakorn, S. and Niwetpathomwat, A. (2007) A 
complicated case of concurrent canine babesiosis and canine ehrlichiosis. Comp. Clin. Pathol., 16: 281-284.

4. Köster, L.S, Lobetti, R.G. and Kelly, P. (2015) Canine babesiosis: A perspective on clinical complications, biomarkers, and treatment. Vet. Med. (Auckl), 6: 119-128.

5. Urquhart, G.M., Dunn, A.M. and Jennings, F.W. (1996) Veterinary Parasitology. $2^{\text {nd }}$ ed. Blackwell Publishers, Hoboken, New Jersey. p234-235.

6. Cardoso, L., Tuna, J., Vieira, L., Yisaschar-Mekuzas, Y. and Baneth, G. (2008) Molecular detection of Anaplasma platys and Ehrlichia canis in dogs from the North of Portugal. Vet. J., 183(2): 232-233.

7. Solano-Gallego, L., Trotta, M., Carli, E., Carcy, B., Caldin, M. and Furlanello, T. (2008) Babesia caniscanis and $B$. vogeli clinicopathological findings and DNA detection by means of PCR-RFLP in blood from Italian dogs suspected of tick-borne disease. Vet. Parasitol., 157(3-4): 211-221.

8. Solano-Gallego, L., Miró, G., Koutinas, A., Cardoso, L., Pennisi, M.G., Ferrer, L., Bourdeau, P., Oliva, G. and Baneth, G. (2011) Leish Vet guidelines for the practical management of canine leishmaniosis. Parasit. Vectors, 4 : 86-10.

9. Boozer, A.L. and Macintire, D.K. (2003) Canine babesiosis. Vet. Clin. North Am. Small Anim. Pract., 33(4): 885-904, viii.

10. Irwin, P.J. (2009) Canine babesiosis: From molecular taxonomy to control. Parasit. Vectors, 2(Suppl 1): S4.

11. Solano-Gallego, L. and Baneth, G. (2011) Babesiosis in dogs and cats expanding parasitological and clinical spectra. Vet. Parasitol., 181(1): 48-60.

12. Badawi, N.M. and Yousif, A.A. (2020), Babesia canis spp. in dogs in Baghdad Province, Iraq: First molecular identification and clinical and epidemiological study. Vet. World, 13(3): 579-585.

13. Leisewitz, A.L., Goddard, A., Clift, S., Thompson, P.N., De Gier, J., Van Engelshoven, J.M. and Schoeman, J.P. (2019) A clinical and pathological description of 320 cases of naturally acquired Babesia rossi infection in dogs. Vet. Parasitol., 271(8): 22-30.

14. Suzuki, K., Wakabayashi, H., Takahashi, M., Fukushima, K., Yabuki, A. and Endo, Y. (2007) A possible treatment strategy and clinical factors to estimate the treatment response in Babesia gibsoni infection. J. Vet. Med. Sci., 69(5): 563-568.

15. Koster, L.S., Van, Schoor, M., Goddard, A., Thompson, P.N., Matjila, P.T. and Kjelgaard-Hansen, M. (2009) C-reactive protein in canine babesiosis caused by Babesia rossi and its association with outcome. J. S. Afr. Vet. Assoc., 80(2): 87-91.

16. Olmeda, A.S., Armstrong, P.M., Rosenthal, B.M., Valladares, B., del Castillo, A., de Armas, F., Miguelez, M., Gonzalez, A., Rodriguez, J.A., Spielman, A. and Telford, S.R. $3^{\text {rd }}$. (1997) A subtropical case of human babesiosis. Acta Trop., 67(3): 229-234.

17. Crnogaj, M., Cerón, J.J., Šmit, I., Kiš, I., Gotić, J., Brkljačić, M., Matijatko, V., Rubio, C.P., Kučer, N. and Mrljak, V. (2017) Relation of antioxidant status at admission and disease severity and outcome in dogs naturally infected with Babesia caniscanis. BMC Vet. Res., 13(1): 114.

18. AbdElKader, N.A., Sheta, E., AbuBakr, H.O., El-Shamy, O.A.A., Oryan, A. and Attia, M.M. (2020) Effects of chitosan nanoparticles, ivermectin and their combination in the treatment of Gasterophilus intestinalis (Diptera: Gasterophilidae) larvae in donkeys (Equus asinus). Int. J. Trop. Insect Sci., 41(2): 43-54.

19. Attia, M.M., El-Gameel, S.M. and Ismael, E. (2020) Evaluation of tumor necrosis factor-alpha (TNF-a); gamma interferon (IFN-c) genes and oxidative stress in sheep: Immunological responses induced by Oestrus ovis (Diptera: Oestridae) infestation. J. Parasit. Dis., 44(2): 332-337.

20. Younis, N.A., Laban, S.E., Al-Mokaddem, A.K. and Attia, M.M. (2020) Immunological status and histopathological appraisal of farmed Oreochromis niloticus exposed to parasitic infections and heavy metal toxicity. Aquac. Int., 28(6): 2247-2262.

21. Snedecor, G.W. and Cochran, W.G. (1989) Statistical Methods. $8^{\text {th }}$ ed. Iowa State Press, Ames.

22. Xu, D., Zhang, J., Shi, Z., Song, C., Zheng, X., Zhang, Y. and Kelly, P. (2015) Molecular detection of vector-borne agents in dogs from ten provinces of China. Parasit. Vectors, 8(1): 501.

23. Li, X.W., Zhang, X.L., Huang, H.L., Li, W.J., Wang, S.J., Huang, S.J. and Shao, J.W. (2020) Prevalence and molecular characterization of Babesia in pet dogs in Shenzhen, China. Comp. Immunol. Microbiol. Infect. Dis., 70(3): 101452.

24. Mittal, M., Kundu, K., Chakravarti, S., Mohapatra, J.K., Singh, V.K., Kumar, B.R. and Kumar, A. (2019) Canine babesiosis among working dogs of organized kennels in India: A comprehensive hematological, biochemical, clinic pathological and molecular epidemiological multiregional study. Prevent. Vet. Med., 169(8): 104696.

25. Veneziano, V., Piantedosi, D., Ferrari, N., Neola, B., Santoro, M., Pacifico, L. and Tyrrell, P. (2018) Distribution and risk factors associated with Babesia spp. infection in hunting dogs from Southern Italy. Ticks Tick Borne Dis., 9(6): 1459-1463.

26. Adebayo, O.O., Ajadi, R.A., Omobowale, T.O., Omotainse, S.O., Dipeolu, M.A., Nottidge, H.O. and Otesile, E.B. (2016) Reliability of clinical monitoring for the diagnosis of babesiosis in dogs in Nigeria. Vet. Med. (Auckl), 7: 85-90.

27. Salem, N.Y. and Farag, H.S. (2014) Clinical, hematologic, and molecular findings in naturally occurring Babesia canisvogeli in Egyptian dogs. Vet. Med. Int., 2014: 270345.

28. Lee, S., Lee, H., Park, J.W., Yoon, S.S., Seo, H.J., Noh, J. and So, B.J. (2020) Prevalence of antibodies against Anaplasma spp., Borrelia burgdorferi Sensu lato, Babesia gibsoni, and Ehrlichia spp. in dogs in the Republic of Korea. Ticks Tick Borne Dis., 11(4): 101412.

29. Zhang, J., Liu, Q., Wang, D., Li, W., Beugnet, F. and Zhou, J. (2017) Epidemiological survey of ticks and tick-borne pathogens in pet dogs in South-Eastern China. Parasite, 24: 35.

30. Asgarali, Z., Pargass, I., Adam, J., Mutani, A. and Ezeokoli, C. (2012) Haematological parameters in stray dogs seropositive and seronegative to Ehrlichia canis in North Trinidad. Ticks Tick Borne Dis., 3(4): 207-211.

31. Ojeda-Chi, M.M., Rodriguez-Vivas, R.I., EsteveGasent, M.D., de León, A.A.P., Modarelli, J.J. and VillegasPerez, S.L. (2019) Ehrlichia canis in dogs of Mexico: Prevalence, incidence, co-infection and factors associated. Comp. Immunol. Microbiol. Infect. Dis., 67(6): 101351.

32. Vargas-Hernández, G., André, M. R., Faria, J. L. M., Munhoz, T. D., Hernandez-Rodriguez, M., Machado, R. Z. and Tinucci-Costa, M. (2012) Molecular and serological detection of Ehrlichiacanis and Babesia vogeli in dogs in Colombia. Vet. Parasitol., 186(3-4): 254-260.

33. Hornok, S., Edelhofer, R. and Farkas, R. (2006) Seroprevalence of canine babesiosis in Hungary suggesting breed predisposition. Parasitol. Res., 99(6): 638-642.

34. Mellanby, R.J., Handel, I.G., Clements, D.N., de Bronsvoort, B.M.C., Lengeling, A. and Schoeman, J.P. (2011) Breed and sex risk factors for canine babesiosis in South Africa. J. Vet. Intern. Med., 25(5): 1186-1189.

35. Martinod, S., Laurent, N. and Moreau, Y. (1986) Resistance and immunity of dogs against Babesia canis in an endemic area. Vet. Parasitol., 19(3-4): 245-254.

36. Farag, H.S. (2012) Epidemiological, Diagnostic and Therapeutic Studies on Canine Babesiosis [M.S. Thesis]. Faculty of Veterinary Medicine, Cairo University, Giza, Egypt.

37. Schetters, T.P., Kleuskens, J.A.G., Van De Crommert, J., De Leeuw, P.W.J., Finizio, A.L. and Gorenflot, A. (2009) Systemic inflammatory responses in dogs experimentally infected with Babesia canis; a hematological study. Vet. Parasitol., 162(1-2): 7-15. 
38. Miró, G., Montoya, A. and Roura, X. (2013) Seropositivity rates for agents of canine vector-borne diseases in Spain: A multicenter study. Parasit. Vectors, 6(1): 117.

39. Solano-Gallego, L., Sainz, Á., Roura, X., Estrada-Peña, A. and Miró, G. (2016) A review of canine babesiosis: The European perspective. Parasit. Vectors, 9(1): 336.

40. Frank, J.R. and Breitschwerdt, E.B. (1999) A retrospective study of ehrlichiosis in 62 dogs from North Carolina and Virginia. J. Vet. Intern. Med., 13(3): 194-201.

41. Niwetpathomwat, A., Techangamsuwan, S. and Suvarnavibhaja, S. (2006) A retrospective study of the clinical hematology and biochemistry of canine ehrlichiosis in an animal hospital population in Bangkok, Thailand. Comp. Clin. Pathol., 14(4): 217-220.

42. Harrus, S., Waner, T., Avidar, Y., Bogin, E., Peh, H. and Bark, H. (1996) Serum protein alterations in canine ehrlichiosis. Vet. Parasitol., 66(3-4): 241-249.

43. Foglia, M.V., Cappiello, S. and Oliva, G. (2006) Ticktransmitted diseases in dogs: Clinicopathological findings. Parasitologia, 48(1-2): 135-136.

44. Zygner, W., Gójska-Zygner, O., Norbury, L.J. and Wedrychowicz, H. (2012) Increased AST/ALT ratio in azotaemic dogs infected with Babesia canis. Pol. J. Vet. Sci., 15(3): 483-486.

45. Wang, J., Zhang, J., Kelly, P., Zheng, X., Li, M., You, J. and $\mathrm{Li}$, J. (2018) First description of the pathogenicity of Babesia vogeli in experimentally infected dogs. Vet. Parasitol., 253(5): 1-7.

46. Zygner, W. and Gójska-Zygner, O. (2014) Increased serum urea to creatinine ratio and its negative correlation with arterial pressure in canine babesiosis. Acta Parasitol., 59(3): 548-551.

47. Zygner, W., Gójska-Zygner, O., Bąska, P. and Długosz, E. (2014) Serum concentrations of tumor necrosis factor in dogs naturally infected with Babesia canis and its relation to severity of disease. Parasitol. Res., 113(4): 1499-1503.

48. Jacobson, L.S., Lobetti, R., Becker, P., Reyers, F. and Scott, T.V. (2002) Nitric oxide metabolites in naturally occurring canine babesiosis. Vet. Parasitol., 104(1): 27-41.

49. Jefferies, R., Ryan, U.M., Muhlnickel, C.J. and Irwin, P.J. (2003) Two species of canine Babesia in Australia: Detection and characterization by PCR. J. Parasitol., 89(2): 409-412.

50. Ionita, M., Mitrea, I.L, Pfister, K., Hamel, D., Buzatu, C.M. and Silaghi, C. (2012) Canine babesiosis in Romania due to Babesia canis and Babesia vogeli: A molecular approach. Parasitol. Res., 110(5): 1659-1664.
51. Uilenberg, G., Franssen, F.F.J., Perie, N.M. and Spanjer, A.A. (1989) Three groups of Babesia canis distinguished and a proposal for nomenclature. Vet. Q., 11(1): 33-40.

52. Elsafey, A.A. (2009) Studies on Some Blood Parasites in Dogs. M.V.Sc. Thesis, Faculty of Veterinary Medicine, Cairo University Giza, Egypt.

53. Abdel-Rhman, A.A., Hegazy, Y.M., Sultan K. and Al-Gaabary M.H. (2015) Clinical, hematological and parasitological: Study on canine babesiosis. Kafrelsheikh Vet. Med. J., 13(2): 37-47.

54. Passos, L.M., Geiger, S.M., Ribeiro, M.F., Pfister, K. and Zahler-Rinder, M. (2005) First molecular detection of Babesia vogeli in dogs from Brazil. Vet. Parasitol., 127(1): 81-85.

55. Codreanu, M.D., Turcitu, M.A., Tudor, P., Tudor, N., Codreanu, I. Fernoaga, C. and Cornila, M. (2011) Genetic characterization of canine babesiosis in Romania Accession No. in GenBank (HQ662635.1).

56. Moraes, P.H., Rufino, C.P., Baraúna, A.R., Reis, T., Agnol, L.T., Meneses, A.M., Aguiar, D.C., Nunes, M.R. and Gonçalves, E.C. (2015) Molecular characterization of Babesia vogeli in dogs from Belém, Northern Brazil. Genet. Mol. Res., 14(4): 16364-16371.

57. Medkour, H., Laidoudi, Y., Marié, J.L., Fenollar, F., Davoust, B. and Mediannikov, O. (2020) Molecular investigation of vector-borne pathogens in red foxes (Vulpes vulpes) from Southern France. J. Wildl. Dis., 56(4): 837-850.

58. Ngoka, I.T., Pelle, R., Kyallo, M., Mbogo, K. and Juma, P. (2020) Molecular Detection of Babesia Species Infecting Dogs from Select Regions in Kenya and their Phylogenetic Relationship. Accession No. in GenBank (MT740272.1).

59. Hsieh, Y.C., Lee, C.C., Tsang, C.L. and Chung, Y.T. (2010) Identification and molecular characterization of a new strain of $B$. vogeli from naturally infected dogs in Taiwan. Exp. Appl. Acarol., 68(3): 539-551.

60. Zanet, S., Bassano, M., Trisciuoglio, A., Taricco, I. and Ferroglio, E. (2017) Horses infected by piroplasms different from Babesia caballi and Theileria equi: Species identification and risk factors analysis in Italy. Vet. Parasitol., 236(4): 238-241.

61. Adaszek, L. and Winiarczyk, S. (2008) Molecular characterization of Babesia caniscanis isolates from naturally infected dogs in Poland. Vet. Parasitol., 152(3-4): 235-241.

62. Vatansever, Z., Gunduz, N., Tasci, G.T., Gokce, E., Uzlu, E. and Kirmizigil, A.H. (2013) Molecular Characterization of Autochthonous Cases of Babesia caniscanis in Turkey. Accession No. in GenBank (KF499115.1).

\section{$* * * * * * * *$}

